6. Onoprienko, V.I., 2010. Biograficheskij metod v psihologii i sociologii [Biographical method in psychology and sociology]. Visnik Nac. aviac. un-tu. Filosofiya. Kulturologiya, 2, pp. 130-136.

7. Popik, V., 2008. Svitoglyadni zasadi rozvitku ukrayinskoyi biografistiki ta formuvannya nacionalnih resursiv biografichnoyi informaciyi XXI st. [World outlook principles for the development of Ukrainian biography and the formation of national resources of biographical information of the 21st century]. Ukrainian biography, 4, pp. 8-41.

8. Rybnikov, Nikolaj Aleksandrovich 1920. Biografii i ih izuchenie [Biographies and their study]. [online] Available at: http://www.psy.msu.ru.

УДК 373.2:004:001.895(045)

DOI: 10.31339/2617-0833-2019-2(27)-141-145

\title{
INFORMATION SUPPORT OF INNOVATION PROCESSES IN PRE-SCHOOL EDUCATION SYSTEM
}

Samoiliuk Svitlana

\section{ІНФОРМАЦЙНА ПЦТРИМКА ІННОВАЦІЙНИХ ПРОЦЕСІВ В СИСТЕМІ ДОШКІЛЬНОї ОСВІТИ}

Самойлюк Світлана

The article reveals the relevance, theoretical and practical importance of the problem of information support for the implementation of innovative processes. Presented and emphasized on the versatility of pre-school education institutions at the present stage. It is stated that innovative processes in the preschool institution did not take place spontaneously, but measured, planned, necessary systematic approach to them.

Key words: quick search, knowledge transfer, information culture, methodological support, information support, preschool institution, tutor.

У статті розкрито актуальність, теоретичне та практичне значення проблеми інформачійної підтримки впровадження нновачійних прочесів. Зазначено, щуоб інновачійні прочеси в дошкільному закладі проходили не стихійно, а розмірено, планово, необхідний системний підхід до них. В першу чергу необхідно виявити ефективні методи вивчення $i$ оцінювання інновачій, чіткий механізм їх реалізації, способи діагностики $і$ формування, визначити готовність педагогів до такої діяльності. Впровадження інновачійних процесів в дошкільний заклад неможливий без методичного забезпечення роботи. У зв язку з цим, виникає необхідність організаџії системи фахової підготовки майбутніх вихователів, яка б забезпечувала прочес формування їхньої готовності до професійного саморозвитку, постійного вдосконалення особистісних та професійних якостей.

Ключові слова: швидкий пошук, передача знань, інформаційна культура, методична підтримка, інформаційна підтримка, дошкільний заклад, вихователь.

The traditional content of education and upbringing at the present stage conflicts with new tasks, working conditions, needs of society. The era of informatization puts forward new requirements for professionals who are forced to combine professional activity with education, and encourages the use of various environmental resources for education and self-education. Therefore, information and communication technologies are most relevant to the needs of today, because they serve as a means of rapid search, processing, transfer of knowledge. Every person, and especially the teacher, in order to realize himself or herself as a professional, must have a well-formed information culture, because it is an important factor for successful professional activity and human 
security in society [1, p.281].

In this regard, there is a need to restructure the activities of preschool education, information, methodological support for training, retraining of specialists.

The problem of informational support of teachers was revealed in research I. Smirnova, O. Znachenko, N. Volkova, A. Stoliarevska etc. At the same time, the analysis of the educational process in the ZDO testifies to the lack of awareness of teachers with modern opportunities, innovative development.

Innovation is an innovation that ensures the qualitative growth of process efficiency, the end result of a person's intellectual activity, his imagination, creative process, discoveries, inventions and rationalization. The term "innovation" comes from the Latin "novation" which means "restoration" and the prefix "in", which translates from Latin as "in the direction", if translated literally "innovatio" - "in the direction of change".

An innovative educational process implies changes in the educational process. It is necessary to modernize the content and forms of upbringing of children, to direct activity on the development of personal qualities, to take into account specific traits of character, mind-set, to create in the group such an environment so that the children felt comfortable and could realize their interests, inclinations, desires, with pleasure to attend preschool education and every day to enrich your yet small amount of knowledge.

It is only a personality-oriented education by virtue of the achievement of a personal developmental goal, since it is directed at the awareness of the pupil as a person, to his free and responsible self-expression. The caregiver's ability to know each child in the unity of his or her individual, ethnic, cultural and social characteristics is paramount in his work. Therefore, innovative training of teachers should focus on the child and his or her living space [2, p. 110].

How to prepare a teacher who can introduce innovative methods in a preschool institution, who understands that only by introducing a new, effective one can achieve a higher level of education and upbringing of children, using the latest scientific and technical knowledge? The reorientation of preschool education to innovative methods of working with children rests with the head of the institution and the methodologist. Implementing innovative methods is a complex process that is learned by different educators in different ways. Therefore, it is necessary to provide teachers with methodological advice on techniques, methods, forms of work.

Effective and qualified introduction of new pedagogical methods requires methodological support which consists of consultations, lectures, discussions, analysis of results, questionnaires.

«Kindergarten», «School World» and other educational editions highlight and promote interesting experiences of scholars and practitioners, innovations, in line with the state policy objectives regarding the role and importance of pre-school education in Ukraine at the present stage. The publication is the forefront of the invention of advanced pedagogical experience at each stage of pre-school education. During the existence of the publication various materials were presented, which presented innovative technologies and techniques from all over Ukraine: this is a technique for the development of broadcasting N. Havrysh, psychological and pedagogical design T. Pirozhenko, ICT in Preschool Education, Developmental Reading by Method L. Shelestova, educational technology "Logic of the world" I. Stetsenko, creative drawing L. Shulha, theater of physical education M. Yefimenka, gameplay M. Shutia, methodology "Learning to Think" (Lviv), museum pedagogy, heritage work S. Rusova, V. Sukhomlynskyi, the revival of spirituality. Within the framework of the scientific and methodological complex "Consortium of Postgraduate Educational Establishments", the All-Ukrainian School of Innovation was created for creative teachers, methodologists, managers of the University of Education Management, where these publications acted as information partners. All-Ukrainian school is an effective form of raising the professional level of management and pedagogical staff of pre-school education [3].

The introduction of information technology tools in a certain way changes the structure of activity of the teacher of the institution of preschool education and significantly updates it. The modern educator is required not only to be able to work with computer equipment, but also to 
creatively apply it to meet their professional daily needs. The organization of the professional activity of educators using IT tools is considered in the following aspects:

1) organization of professional activity during the stages of preparation and conducting of lessons with preschool children using IT (selection of visuals, computer games; creation of didactic materials, computer exercises, etc.); creation of methodological materials and organizational documents;

2) organization of professional activity of preschool teachers with the use of IT tools for advanced training (use of the Internet, e-mail services, e-blogs, sites, chat rooms for communication, distance learning) [4, p. 112-123].

Implementation of innovative technologies into the institution of preschool education is the command of time. However, it should be borne in mind that pedagogical technologies used in the educational process of the preschool institution are subject to requirements. It should be noted that successful implementation of innovative technologies in the educational process of a preschool institution requires methodical support: it is necessary to solve the task of improving the qualification of teaching staff. An optimal system of methodological measures should be created in the HLT and teachers should be given the right to freely choose the forms that best meet their needs, requests and interests.

Methodical work is a systematic collective and individual activity of pedagogical staff aimed at increasing their scientific-theoretical, general cultural level, psychological and pedagogical training and professional skill.

Methodological work at the Preschool Education Institution is a holistic system of interdependent actions and measures aimed at comprehensive training and professional skill of each educator (including measures to manage professional self-confidence, teachers), for the development and enhancement of the creative potential of the pedagogical staff of the IDA as a whole, and ultimately - to improve the educational and educational process in, achieving the optimal level of education and the development of specific children.

The structure of the methodological work includes interrelated elements that meet the goals and objectives of the school and are embodied in different forms, different methods and means. It is logical to use innovation in methodical work [5]. Innovative forms of methodical work are divided by:

- methods of collective creativity (fairs of pedagogical creativity, festivals of pedagogical ideas, pedagogical placers, clubs of creative pedagogues, methodical tournaments, schools of pedagogical skill, creative portraits and laboratories).

- Forms that prompt teachers to engage in active activities (methodical rings, methodical auctions, business games, pedagogical consultations, sit-ins, workshops).

- Forms that enhance the scientific focus of the work (creative groups, problematic seminars, creative scientific discussions, consultations with scientists, educational seminars on the method of pedagogical research, authoring schools of skill, debate, creative laboratories).

- Forms that enhance the practical orientation of the work (consultations-workshops, beginner teacher's schools, training seminars).

- Forms that combine traditional work with leisure (pedagogical sessions, evening parties, presentations of pedagogical novelty, pedagogical portrait of a creative team).

The most effective are such non-traditional innovative forms of methodological work with teachers, namely: methodical festivals, dialogues, bridges, rings; seminars-satellites; pedagogical consultations and trainings; brain attacks; psychological and pedagogical discussions; problem tables; pedagogical tournaments, etc. [6].

The success of innovative methodological activities depends on the organization and involvement of team members, their preparation:

1. It is necessary to inform the team first about the topic, purpose, conditions, tasks and date of the event.

2.Create an information corner, where ads, assignments, lists of recommended literature are 
placed.

3. Organization of an exhibition of necessary materials and literature in the methodological office.

4.Consulting members of the team, providing them with some assistance.

Creating an appropriate scientific and methodological environment enables the educator to seek new means of pedagogical activity, to develop pedagogical skills through constant critical reflection on his own experience and new ideas.

Therefore, the organization of methodological support of innovative pedagogical activity of a preschool institution is the key to improving the efficiency of educational work in preschool educational institutions [7].

It is necessary to pay attention to the system of scientific and methodological work in the educational institution, which gives the opportunity to the leaders and coordinators of the experimental work to introduce into the activity of pedagogical collectives of schools and institutions of preschool education appropriate changes:

- determine the structure of research work for a particular educational institution;

- to build the program of the experiment and to determine the problem, purpose, hypothesis of the research, the method of recruitment of respondents (formation of control, experimental groups), methods, tasks of the research;

- to determine the plan of the experiment;

- to analyze the obtained results (both positive and negative), to create a system of scientific work of the department with pedagogical teams of schools and institutions of pre-school education.

In order to overcome the lack of professional competence of educators on the issues of scientific, methodological and experimental work in the training of specialists, it is necessary to provide information and scientific and methodological support for the development of innovative activity of educational institutions:

- holding scientific forums that facilitate the exchange of experience, professional development of employees;

- development and implementation of professional special courses in the system of advanced training such as: "Methodology of conducting educational quality monitoring studies"; "Management of scientific and methodological work in educational institutions"; "Management of educational process in a preschool educational institution on the basis of monitoring procedures", "Modernization of education in modern conditions of development of postgraduate pedagogical education"; "Methodology of monitoring the quality of primary education"; "Management of the process of forming didactic competence of the head, pedagogical team", etc. The purpose of the special courses is the formation of methodological and theoretical competence in the management of scientific and methodological work and didactic competence of preschool teachers [8]. During their education, teachers develop their own complex-purpose projects, modern models of educational institution development and factor-criteria models for determining the quality of their implementation:

- methodical consultations: how to include development in the curriculum, what methods, methods, forms of work to apply, implementing innovative methods or part of them;

- lectures on problems of implementation, demonstration of methods, techniques and forms of work with their subsequent discussion;

- problematic conversations;

- seminars - presentations, trainings.

Investigating the work of the Educational and Educational Complex "Pervotsvit" in Mukachevo, they found that the structure of the methodological work of the NVC "Pervotsvit" constitutes a holistic system of interrelated actions and measures aimed at comprehensive improvement of the professional level of the pedagogical team: teachers of primary and secondary school teachers subjects and is aimed at developing the initiative and creativity of each teacher. Methodical activity of educational complex is aimed at teaching the teacher, class teacher, teacher 
how to find for each child the key of development of her creative gifts, her success in the system "kindergarten-school", since the main feature of modern changes in the education system is its reforming. on the principles of continuity.

\section{References}

1. Dziuba, V. and Tsoi, M., 2003. Problemy orhanizatsii innovatsiinoi diialnosti v systemi doshkilnoi osvity [Problems of organization of innovative activity in the system of preschool education]. Education and Management, 1, 6, p. 110.

2. Konsortsium zakladiv pisliadyplomnoi osvity [Consortium of Postgraduate Education Institutions]. [online] Available at: http://umo.edu.ua/vseukrajinsjka-ghromadsjkaorghanizacija-konsorcium-zakladiv-pisljadiplomnoji-osviti [Accessed 5 December 2018].

3. Kuzemko, L. V. and Kuzavka, I. V., 2015. Pedahohichni umovy pidhotovky maibutnikh vykhovateliv do proektuvannia kompiuternykh dydaktychnykh ihor dlia doshkilnykiv [Pedagogical conditions for preparing future educators to design computer-based didactic games for preschoolers]. Young Scientist: Scientific Edition, 5, pp. 112-123.

4. Metodychnyi suprovid innovatsiinoi diialnosti v doshkilnomu zakladi [Methodical support of innovative activity in preschool institution]. [online] Available at: https://abetkaland.in.ua/metodychnyj-suprovid-innovatsijnoyi-diyalnosti-v-dnz/.

5. Honcharenko, S. and Malovanyi, Yu., 1994. Intehrovane navchannia. Za i proty [Integrated learning. For and against]. Education, 15-16, p.5.

6. Dychkivska, I.M. 2012. Innovatsiini pedahohichni tekhnolohii [Innovative pedagogical technologies]. 2nd ed. Kyiv.

7. Marmaza, O.I. 2004. Innovatsiini pidkhody do upravlinnia navchalnym zakladom [Innovative Approaches to School Management]. Kharkiv: Osnova(Basis).

8. Derzhavnyi standart pochatkovoi osvity [State standard of primary education]. [online] Available at: http://dano.dp.ua/attachments/article/B8.pdf.

УДК 373.3.015.311(045)

DOI: 10.31339/2617-0833-2019-2(27)-145-149

\section{ПЕДАГОГІЧНІ УМОВИ ФОРМУВАННЯ ТВОРЧОЇ ОСОБИСТОСТІ МОЛОДШОГО ШКОЛЯРА}

Сігетій Крістіна

\section{PEDAGOGICAL CONDITIONS FOR THE FORMATION OF THE CREATIVE PERSONALITY OF THE ELEMENTARY STUDENT}

Sighetii Kristina

Життя висунуло суспільний запит на виховання творчої особистості, здатної на відміну від людини виконавия, самостійно мислити, генерувати оригінальні ідеї, приймати сміливі нестандартні рішення. Але педагоги констатують щэо випускники шкіл ще не здатні самостійно розв'язувати проблеми, не можуть мислити діалектично, системно, легко переходити від одного виду діяльності до іншого. Їм не вистачає творчої уяви, інічіативи, винахідливості. Такий стан справ вимагає якісно нового підходу до підготовки молоді до життя. Орієнтиром змісту науки є робота над формуванням нової розвиненої, творчої особистості.

Ключові слова: творчість, творча особистість, творчі здібності, розвиток, формування, ініціатива, індивідуальність.

Life has raised a public demand for the education of a creative personality, capable of 